\title{
Modelling of microbial enhanced oil recovery application using anaerobic gas-producing bacteria
}

\author{
Pavel Spirov $^{1}$, Yanina Ivanova ${ }^{2}$ and Svetlana Rudyk ${ }^{1 *}$ \\ ${ }^{1}$ Department of Petroleum and Chemical Engineering, Sultan Qaboos University, Muscat 123, Sultanate of Oman \\ ${ }^{2}$ Chemistry \& Environment, Mærsk Olie og Gas A/S, Kanalen 2 DK-6700 Esbjerg, Esbjerg 6700, Denmark
}

(C) China University of Petroleum (Beijing) and Springer-Verlag Berlin Heidelberg 2014

\begin{abstract}
Microbial enhanced oil recovery (MEOR) methods apply injection of bacteria to depleted oil reservoirs to produce oil, which had remained unrecovered after the conventional methods of production. The ability of thermophilic anaerobic bacteria to produce gas as the main mechanism in potential MEOR in high salinities of 70-100 g/L was investigated in this study. Maximum gas production of up to $350 \mathrm{~mL}$ per $700 \mathrm{~mL}$ of salty solution was produced at a salinity of $90 \mathrm{~g} / \mathrm{L}$ stably during 2-4 days of experiment. The experimental results were upscaled to the Snorre Oilfield, Norway, and simulated using ECLIPSE software for 27 months. The best scenarios showed that the increase in oil recovery on average was at $21 \%$ and $17.8 \%$ respectively. This study demonstrated that anaerobic bacteria used in biogas plants could be an attractive candidate for MEOR implementation due to their ability to withstand high temperature and salinity, and produce gas in large volumes.
\end{abstract}

Key words: Microbiological enhanced oil recovery, $\mathrm{CO}_{2}$ injection, ECLIPSE simulation

\section{Introduction}

Fossil fuels are one of the main energy resources that people need for living in modern society. There are a lot of questions about so called 'black gold' and how long it will be possible to produce it in the future. Today's society is highly dependent on oil and gas in various forms of petroleum products - from fuel for cars to polyethylene bags. Nowadays there is a demand for more fossil fuels because of the fast growing world population. Prognoses show that oil and gas production will be inadequate to meet the world needs. Fast developing countries such as China, India, and Brazil are steadily increasing their consumption of petroleum products. However, the oil and gas production from so called 'easy found' fields is constantly decreasing. If successful techniques for extracting the residual hydrocarbons in the reservoirs are not applied, the industrial countries will be facing a serious problem. Therefore, the application of new environmentally friendly oil recovery techniques will lead to a sustainable development of the energy sectors for the coming years. Sayyouh et al (1993) estimated that the initial oil-in-place in Saudi Arabia was approximately 700 billion barrels and only around 250 billion barrels could be extracted by conventional production techniques. More than 90 billion barrels could be added to Saudi Arabia's proven reserves if only $20 \%$ out

*Corresponding author. email: svetrud77@mail.ru

Received February 6, 2013 of the 450 billion barrels remaining in-place were produced through enhanced oil recovery techniques. The microbial enhanced oil recovery (MEOR) method was estimated as a potential cost-effective recovery method for some of the Middle East reservoirs.

The MEOR process, which has gathered increasing interest in recent years, has a number of advantages in comparison with other enhanced oil recovery (EOR) methods. This method consists of injection into the reservoir of fermentative bacteria and/or nutrients producing large amounts of gas, acids, and solvents, thus increasing the oil recovery. It is environmentally friendly since only biological substances are used and can contribute to the future sustainable development in the enhanced oil recovery sector. This technology has been developing from laboratory experiments from the early 1980s to field application in the 1990s.

A successful example of MEOR technique in practice is the Beatrice offshore field, UK. This field was scheduled for abandonment in 1996, but due to the successful MEOR method, it continued to produce. According to Lazar et al (2007), the MEOR procedure was applied between 1975 and 1983 in a Romanian field test. In Germany, MEOR was applied to dolomites of Zechstein formations of the Doerban field in 1982 as reported by Wagner (1991). The formation pressure was approximately $80 \mathrm{bars}$, and the temperature was approximately $53{ }^{\circ} \mathrm{C}$. He reported that the formation was filled with high salinity water and even fractures were 
partially filled with salt. The results of the MEOR applications were reported as follows: water cut decreased from $80 \%$ to $60 \%$; average annual oil production before bacterial treatment was 50 tonnes/month, increasing to 150 tonnes/month 3 months after the injection and 300 tonnes/month after 1 year.

From an economical point of view, the MEOR method is the second cheapest after the water injection technique, which means it has a great advantage to be developed sustainably in the next decades. Microbial processes use less energy as compared to the thermal processes; they also do not depend on the crude oil price as many other chemical processes do. The microbial growth occurs at exponential rates, so it is supposed that large quantities of useful products can be produced fast from cheap and renewable resources.

Although MEOR techniques were developed long ago, they have slowly become recognized within the industry (Youssef et al, 2009). The main reasons for this can be the absence of published data in journals, lack of understanding of the method and limited cooperation between reservoir engineers, microbiologists, geologists and economists. Another reason is that microbes do not always behave in the same manner under laboratory conditions and in the reservoir, hence laboratory trials cannot predict the result expected in the field. The main question is whether the microbial process would yield useful products in quantities and at rates that are required for a significant oil recovery (Brown, 2010).

Microbes of different types can be used (anaerobic, aerobic, thermophilic, and mesophilic) that are producing a number of chemicals due to their metabolism. Some of the known bacteria are Clostridium, Bacillus, Escherichia, Micrococcus, Peptococcus, et cetera. The type of byproducts produced by them and their quantity depend on the specific bacterial colony, the nutrients introduced for its growth, and the environmental conditions. Some of the produced chemicals include hydrogen, carbon dioxide, methane, polymers, poly-anionic lipids, alcohols and ketones (Donaldson et al, 1989).

Lazar et al (2007), from 1988 to 1990, used adapted mixed enrichment cultures (AMEC), dominated by Bacillus, Clostridium, and some Gram-negative rods. It can be concluded that the usual species of bacteria injected in wells are Clostridium and Bacillus (Youssef et al, 2009).

The important task to consider when developing MEOR plans is to adjust the microbes to the reservoir conditions high temperature, high pressure and high salinity as well as low permeability and taking into consideration the presence of toxic elements (Donaldson et al, 1989). It has been found that the temperature at $1,000 \mathrm{~m}$ is approximately $45^{\circ} \mathrm{C}$, which is the limiting factor for a large number of microbes under laboratory conditions. However, there are some bacteria living in oil reservoirs up to a depth of 2,000 $\mathrm{m}$ with temperature of approximately $63{ }^{\circ} \mathrm{C}$ and pressure $20 \mathrm{MPa}$. These bacteria are either indigenous, or have been introduced into the reservoir during drilling operations, or by water injection during secondary oil recovery. A problem for the growth of the microbes is the absence of important nutrients in the reservoir. Hence, the nutrients required should be injected in sufficient amounts in order to provide the growth of the bacteria in situ. Molasses are one of the widely used sources of carbohydrates.

It has been proposed that any microbial cultures which will be used for in-situ applications should be studied in a laboratory with conditions similar to the actual reservoir environment. Investigations have shown that bacteria can adapt easily to new circumstances through the process of mutation. This means that the laboratory experiments can be conducted with gradual changes to the environmental conditions.

For the current study, laboratory investigations were conducted using anaerobic bacteria provided by the Ribe Biogas Plant, Denmark. These bacteria produce methane and carbon dioxide. Biogas plants use different types of bacteria sources using manure or corn silage and produce biogas at different temperatures up to $53{ }^{\circ} \mathrm{C}$. At Ribe Plant, biogas is produced from manure and other organic wastes from the agriculture, industry and households. The slurry at the Ribe Biogas Plant is heated to $53{ }^{\circ} \mathrm{C}$, which means that the process is thermophilic. A biological decomposition process occurs in the reactor where the bacteria produce gas. An important parameter is the chemical composition of the biogas. The main compounds of Ribe biogas are methane (64.8\%) and carbon dioxide (35\%). The concern is with the amount of hydrogen sulfide production since it is toxic and can cause corrosion of metals. The amount of $\mathrm{H}_{2} \mathrm{~S}$ in the produced biogas mainly depends on the type of waste used for its production and the amount of sulfur in it. The removal of the hydrogen sulfide occurs through some chemical process, for example in many Danish biogas plants this is done by oxidation with air. The bacterial production of hydrogen sulfide decreases with time. According to Sørensen (2007), $\mathrm{H}_{2} \mathrm{~S}$ is $0.2 \%$ of the Ribe Plant gas.

The purpose of the conducted experimental study was about the ability of the selected microbial consortium to produce gas as the main mechanism in potential MEOR for the selected field. The selected microbial consortium was anaerobic bacteria from the Ribe Biogas Plant. Investigation whether the consortium performs well under reservoir conditions such as high salinities is described in this paper. The results of the laboratory experiments are upscaled to the performance in the field conditions of the Snorre Field, North Sea by pseudo MEOR simulation following different scenarios of gas and water injections using Eclipse software from Schlumberger Company over 27 months.

The injection of bacterial solution with nutrients was simulated as water injection rate (WIR) and bacterial gas production was simulated as gas injection rate (GIR) in Eclipse software. Injection well P-32 (divided into P-32G and P-32W) was used as an injector for the both GIR and WIR and results of the simulation were observed in producer P-39. The distance between P-32 and P-39 is 1,550 m.

\section{Materials and methods}

\subsection{Materials}

The anaerobic bacteria were obtained from the Ribe Biogas Plant, Denmark. The digestive manure was obtained directly from the digester and transported in the thermally 
insulated container to the university laboratory, where it was inserted into the oven with stable temperature of $53{ }^{\circ} \mathrm{C}$.

Sodium chloride $(99.98 \%)$ was purchased from the ProLab Company. Molasses were supplied by Nordic Sugar to be used as a nutrient source for bacteria growth.

The bacterial consortium in the thermophilic anaerobic digester according to Weiss et al (2008) consisted of: Thermoacetogenium sp., Anaerobaculum mobile, Clostridium ultunense, Petrotogasp., Lactobacillus hammesii, Butyrivibrio sp., Syntrophococcus sucromutans, Olsenella sp., Tepidanaerobacter sp., Sporanaerobacter acetigenes, Pseudoramibacter alactolyticus, Lactobacillus fuchuensis, Lactobacillus sakei, Lactobacillusparabrevis, Lactobacillus spicheri and Enterococcus faecalis and others.

The archea present in the anaerobic digester were investigated by Weiss et al (2008) and they are: Methanobrevibacter sp., Methanoculleus bourgensis, Methanosphaera stadtmanae, Methanimicrococcus blatticolaand, Methanomicrobiales.

\subsection{Preparation of the solution}

The digestive manure obtained the same day as the experiments started was used as the inoculum. $50 \mathrm{~mL}$ of digestive manure was added to previously prepared bottles each with the same volume of nutrients and various salt solutions. $10 \mathrm{~g}$ of chalk was added to each the bacterial solution to neutralize the acid, increase $\mathrm{pH}$ and create better conditions for the microbial development (Jimoh et al, 2011).

Four solutions of different salinities were prepared in fermentation bottles of $1 \mathrm{~L}$ volume by accurately weighing a specific amount of sodium chloride and dissolving it in 500 $\mathrm{mL}$ of de-ionized water to make salinities of 70,80, 90 and $100 \mathrm{~g} / \mathrm{L}$. To dissolve salt completely, a magnetic stirrer was used to obtain a homogenized solution.

The fermentation bottles were initially purged of air by passing pure nitrogen through them for about 5 minutes. This was done to create anaerobic conditions in the bottles. The nutrient, consisting of $5 \mathrm{~mL}$ molasses, was added to each bottle with salt solution.

\subsection{Experimental setup for gas collection and measurement}

The setup was completed with water displacement apparatus for gas collection and measurement as shown in Fig. 1. The heating of the process was carried out in a water bath (4) where the temperature was kept at $53{ }^{\circ} \mathrm{C}$ for the 6 days of the experiment. The solution with the inoculum consisted of the mixture of salty water, digestive manure containing anaerobic bacteria, chalk and molasses was prepared in a bottle (1).

The bottle (1) was sealed with a rubber stopper (5) with one outlet (6) for produced gas which flowed to the bottle (2). The outlet (6) was a glass tube placed in the rubber stopper. Bottles (1) and (2) were connected by a plastic pipe (10) attached to the produced gas outlet (6) and gas inlet (8) in the bottle (2). In order to revitalize bacteria, the rubber stopper (5) could be opened and a new portion of molasses and salt solution added to the bottle (1). Before the rubber stopper was opened, the produced gas was measured in the bottle (3).

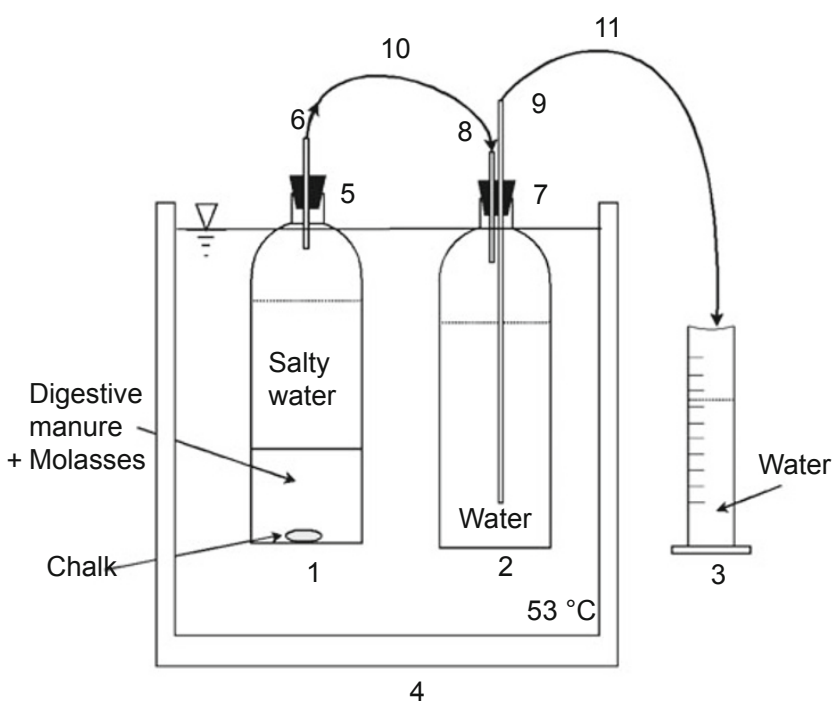

Fig. 1 Experimental setup

1. Bottle with inoculum and chalk; 2. Bottle with water; 3 . Water with displaced water from bottle 2; 4 . Water bath; 5, 7 Rubber stoppers; 10, 11 Plastic tubes connecting bottles

The bottle (2) was occupied by water and air and sealed with a rubber stopper (7) with gas inlet (8) and water outlet (9).

The bottle (3) was a graduated cylinder where the displaced water from the bottle (2) was transported by a plastic pipe (11), collected and measured.

Gas produced by bacteria in the bottle (1) displaced water in the bottle (2) and the amount of water displaced from the bottle (2) to the bottle (3) was equal to the amount of gas in milliliters produced by the bacteria.

By this arrangement, gas production was controlled and measured every day.

The cumulative gas production was calculated as the total sum of gas produced during a period of 120 hours. In order to avoid the interruption of the process and keep the required temperature, $\mathrm{pH}$ and other parameters were not measured.

\section{Results and discussion}

\subsection{Experimental results}

Salinity gradients can occur in the reservoir due to the constant water injection. The bacteria are expected to populate the areas of the oil reservoir where the salinity remains high. For this reason, bacteria were exposed to a broad range of salinities to check their salt tolerance.

Fig. 2 shows gas volumes produced at different salinities over a period of 6 days. Volumes of produced gas were measured daily.

Gas production from the sample with a salinity of $80 \mathrm{~g} /$ $\mathrm{L}$ did not exceed $100 \mathrm{~mL}$ for any day. Because small portion of inoculum was added to water, probably most active gas producing bacteria were not present. The maximum production on the $1^{\text {st }}$ day was achieved for a sample of $80 \mathrm{~g} /$ $\mathrm{L}$ salinity. On the $2^{\text {nd }}$ day of the experiment, $5 \mathrm{~mL}$ of molasses and $200 \mathrm{~mL}$ of salty water were added in order to revitalize the bacteria and activate gas production. The gas production increased sharply at all salinities, especially at 70 and $90 \mathrm{~g} /$ 


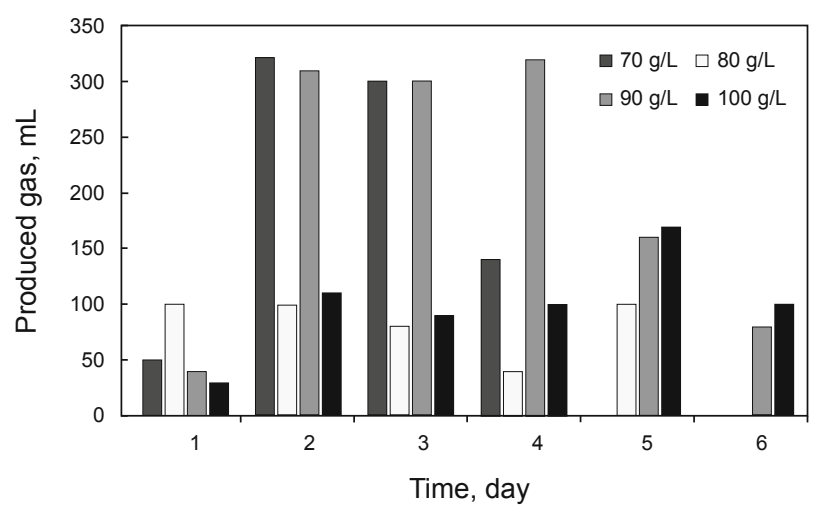

Fig. 2 Gas volumes produced at different salinities over 6 days

L. It can be seen that up to the $4^{\text {th }}$ day, the gas was produced at all salinities. On the $5^{\text {th }}$ day, the sample at salinity of $70 \mathrm{~g} /$ $\mathrm{L}$ ceased gas production. The sample with a salinity of $90 \mathrm{~g} /$ $\mathrm{L}$ decreased in its gas production sharply from $320 \mathrm{~mL}$ to $160 \mathrm{~mL}$. Only the sample at a salinity of $100 \mathrm{~g} / \mathrm{L}$ showed the highest production of $170 \mathrm{~mL}$. On the last day of the experiment, only two solutions at salinities of 90 and $100 \mathrm{~g} / \mathrm{L}$ still produced gas.

As can be seen in Fig. 2, the largest amount of gas was produced at the salinities of 70 and $90 \mathrm{~g} / \mathrm{L}$ of $\mathrm{NaCl}$ at average volume of 135 and $202 \mathrm{~mL}$ respectively during six days. The lowest amount of gas was produced by the sample of a salinity of $80 \mathrm{~g} / \mathrm{L}$, which was $70 \mathrm{~mL}$ on average during the whole period.

It can be seen from Fig. 2 that gas production at different salinities varied substantially. A low gas volume was produced on the $1^{\text {st }}$ day at all salinities. The gas production sharply increased at a salinity of $70 \mathrm{~g} / \mathrm{L}$ on the $2^{\text {nd }}$ day declining and completely ceasing by the $5^{\text {th }}$ day. At a salinity of $80 \mathrm{~g} / \mathrm{L}$, the gas production did not exceed $100 \mathrm{~mL}$ through 5 days of observation. The level of gas production at $90 \mathrm{~g} / \mathrm{L}$ remained above $300 \mathrm{~g} / \mathrm{L}$ during 3 days beginning from the second day and ceased by the $6^{\text {th }}$ day. The gas production at a salinity of $100 \mathrm{~g} / \mathrm{L}$ varied from $90 \mathrm{~g} / \mathrm{L}$ to $170 \mathrm{~g} / \mathrm{L}$ during last five days. If the bacterial gas production when applied to the oil reservoir follows the described trends of the laboratory gas production, different results are expected that could be modeled using software to select best schedule of MEOR applications.

\subsection{Modeling in software}

ECLIPSE was used to model 10 different scenarios, where first simulation is the base case and the remaining nine simulations are based on the results of the previous laboratory investigations to model MEOR performances. The software was tested previously for FAWAG (foam-assisted water alternating gas) application to the Western Fault Block (WFB) of the Snorre Field in Norway to obtain a match with historical production data, and proved to be reliable as described in previous research (Spirov et al, 2012).

The Snorre field reservoir is made of massive sandstone fluvial deposits. The reservoir pressure is higher than 38.3 $\mathrm{MPa}$ at a depth of $2,475 \mathrm{~m}$ in the Statfjord and Lunde formations. The permeability are 400-3,500 $\mathrm{mD}$ (Skauge et al, 2002), average porosity $20 \%-25 \%$ and the reservoir temperature is $90^{\circ} \mathrm{C}$.

The objective of the simulation was to obtain the injection scheme applied to the injector P-32 providing the maximum oil production rate in the producer P-39 (Aarra et al, 2002; Skauge et al, 2002). This well pair, located at a distance of $1,550 \mathrm{~m}$, was chosen to compare the simulated MEOR production results with the actual production results of FAWAG performed on the Snorre Field.

The objective of the simulation was to estimate the well production characteristics assuming that bacterial solution was injected instead of only sea water in the same volume taking the actual water injection rate of $6,000 \mathrm{Sm}^{3} /$ day according to the injection pattern (Spirov and Rudyk, 2013) as a basis for several scenarios.

As the simulator has no special simulation model for MEOR application, the injected fluid consisting of inoculum, water and molasses was simulated as water injection. The gas produced by bacteria was modeled as a gas injection. The gas volume was calculated on the basis of experimental results and upscaled to the gas amount produced by a specific volume of water containing the bacterial solution. For example, $250 \mathrm{~mL}$ of gas was produced on the second day and $125 \mathrm{~mL}$ on the third of experiment in the bottle containing $500 \mathrm{~mL}$ of water. In the simulation scenario, the volumes of injected gas on the second and third days are two and four times less respectively than the volume of injected water in a first day. Because two displacing agents such as gas and water were implemented, the variations of their ratio were tested to estimate their contribution in oil production. Each scenario employed certain water and gas injection volumes following various injection schedules and represented the repeated cycles including the specific sequences of water and gas injections shown in Table 1.

Table 1 MEOR injection scenarios according to the experimental results

\begin{tabular}{|c|c|c|c|c|}
\hline Scenario & $\begin{array}{c}\text { Water injection } \\
\mathrm{Sm}^{3} / \text { day }\end{array}$ & Days of injection & $\begin{array}{c}\text { Gas injection } \\
\mathrm{Sm}^{3} / \text { day }\end{array}$ & $\begin{array}{l}\text { Days of } \\
\text { injection }\end{array}$ \\
\hline 1 & 6000 & Everyday & 0 & 0 \\
\hline 2 & 6000 & Everyday & 3000 & Everyday \\
\hline 3 & 12000 & Everyday & 3000 & Everyday \\
\hline 4 & 6000 & Everyday & 4500 & Everyday \\
\hline 5 & 10000 & Everyday & 5000 & Everyday \\
\hline \multirow{3}{*}{6} & 3000 & $1^{\text {st }}$ day & 1500 & $1^{\text {st }}$ day \\
\hline & 5000 & $2^{\text {nd }}$ day & 2500 & $2^{\text {nd }}$ day \\
\hline & 6000 & $\begin{array}{l}\text { From the } 3^{\text {rd }} \\
\text { day constant }\end{array}$ & 3000 & $\begin{array}{l}\text { From the } 3^{\text {rd }} \\
\text { day constant }\end{array}$ \\
\hline \multirow[b]{2}{*}{7} & \multirow[b]{2}{*}{6000} & \multirow[b]{2}{*}{ Everyday } & 3000 & $1^{\text {st }}$ day \\
\hline & & & 5000 & $\begin{array}{l}\text { From the } 2^{\text {nd }} \\
\text { day constant }\end{array}$ \\
\hline \multirow{4}{*}{8} & \multirow{4}{*}{6000} & \multirow{4}{*}{ Everyday } & 3000 & $1^{\text {st }}$ day \\
\hline & & & 3000 & $2^{\text {nd }}$ day \\
\hline & & & 5000 & $3^{\text {rd }}$ day \\
\hline & & & & Repeated again \\
\hline 9 & 7500 & Every fourth day & $\begin{array}{c}3500,1600, \\
1200,500, \\
3500, \cdots\end{array}$ & $\begin{array}{c}\text { Continuous } \\
\text { pattern }\end{array}$ \\
\hline 10 & 6000 & $\begin{array}{c}\text { One week on, next } \\
\text { week off }\end{array}$ & 3000 & $\begin{array}{c}\text { One week on, } \\
\text { next week off }\end{array}$ \\
\hline
\end{tabular}


The modifications in pseudo MEOR simulation were made from the $1^{\text {st }}$ of November 1996 to the $1^{\text {st }}$ of May 1997 (Fig. 3 ). Water and gas were injected in slugs or simultaneously depending on the simulated scenario.

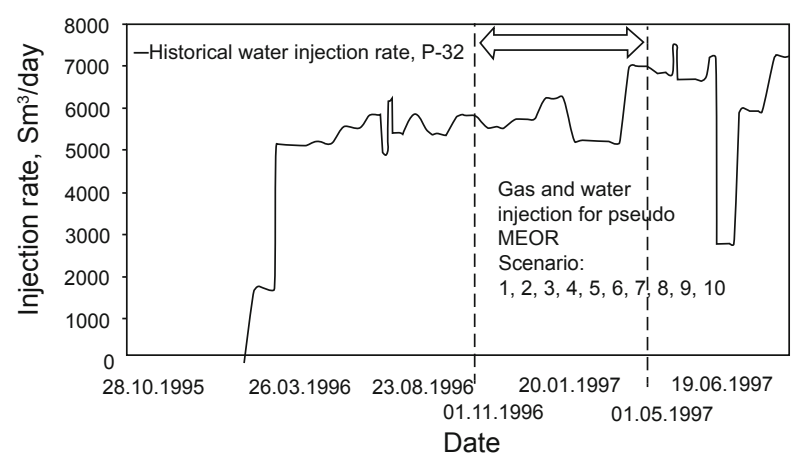

Fig. 3 Water and gas injection in pseudo MEOR simulation

In this work injection gas is produced gas. The amount of produced gas imitates gas produced in the laboratory experiment. In these terms, gas is the fixed parameter. The water amount was variable, which can influence MEOR performance.

Scenario 1 simulated only water injection where 6,000 $\mathrm{Sm}^{3} /$ day of water was injected with no gas during 6 months to be used as the pattern for the comparison to the MEOR simulations. The simulation for the Scenario 1 started on the $1^{\text {st }}$ of November where water injection keyword is inserted. The simulation is altered to simulate the water injection of $6,000 \mathrm{Sm}^{3}$ for each day of simulation from the $1^{\text {st }}$ of November 1996 to the $1^{\text {st }}$ of May 1997.

The simulations were performed at the assumption that the gas was not produced in the first day of water injection. Gas production starts on the second day of water injection.

Scenario 2 simulated that the volume of produced gas was equal to the half of the injected water volume. It is seen from Fig. 2 that $500 \mathrm{~mL}$ of microbial solutions at $90 \mathrm{~g} / \mathrm{L}$ of salinity after the addition of $200 \mathrm{~mL}$ of salty water produced $300 \mathrm{~mL}$ of gas on average stably during 3 days. In this option, water injection in amount of $6,000 \mathrm{Sm}^{3} /$ day started on the $1^{\text {st }}$ of November 1996. Gas injection for simulation started on the $2^{\text {nd }}$ of November 1996 where gas produced by anaerobic digestion bacteria was $3,000 \mathrm{Sm}^{3} /$ day. The water injection and gas production ended on the $1^{\text {st }}$ of May 1997.

Scenario 3 was intended to test whether larger water volumes can improve recovery and uses water injection of $12,000 \mathrm{Sm}^{3} /$ day and constant gas production of $3,000 \mathrm{Sm}^{3} /$ day. The water injection in simulation started on the the $1^{\text {st }}$ of November 1996 and gas production started on the $2^{\text {nd }}$ of November 1996. The last date of simulation alteration where $12,000 \mathrm{Sm}^{3}$ of water and $3,000 \mathrm{Sm}^{3}$ gas was injected was on the $1^{\text {st }}$ of May 1997.

According to Scenario 4, 6,000 $\mathrm{Sm}^{3} /$ day of water from the $1^{\text {st }}$ of November was injected followed from the $2^{\text {nd }}$ of November 1996 by gas production of $4,500 \mathrm{Sm}^{3} /$ day. The injection and production ended on the $1^{\text {st }}$ of May 1997.

In order to investigate the effect of water volume, the water injection was increased to $10,000 \mathrm{Sm}^{3} /$ day and gas production to $5,000 \mathrm{Sm}^{3} /$ day respectively in Scenario 5 . The water injection started on 01.11.1996 and the gas production started on 02.11.1996.

Scenario 6 implies different volumes of water and gas injection varying during 4 days because it was observed that on every fourth day, molasses should be injected in order to revitalize the bacteria. From the startup date of water injection (01.11.1996), 3,000 $\mathrm{Sm}^{3}$ of water had been injected.

On the $2^{\text {nd }}$ day (02.11.1996), 5,000 $\mathrm{Sm}^{3}$ of water had been injected and 1,500 $\mathrm{Sm}^{3}$ of gas had been produced. On the $3^{\text {rd }}$ (03.11.1996), 6,000 $\mathrm{Sm}^{3}$ of water had been injected and 2,500 $\mathrm{Sm}^{3}$ of gas injected. On the $4^{\text {th }}$ day of simulation (04.11.1996), $3,000 \mathrm{Sm}^{3}$ of gas and $6,000 \mathrm{Sm}^{3}$ of water had been injected. For rest of the simulation (04.11.1996-01.05.1997), the water injection rate was $6,000 \mathrm{Sm}^{3} /$ day and the gas injection was $3,000 \mathrm{Sm}^{3} /$ day (04.11.1996-01.05.1997).

In scenario 7, 6,000 $\mathrm{Sm}^{3} /$ day of water had been injected from 01.11.1996 to 01.05.1997. 3,000 $\mathrm{Sm}^{3}$ of gas had been produced on 02.11.1996. From the $3^{\text {rd }}$ of November 1996, $5,000 \mathrm{Sm}^{3} /$ day of gas had been produced and was kept constant throughout the period of simulation (03.11.199601.05.1997).

The water injection rate was $6,000 \mathrm{Sm}^{3} /$ day for all periods of simulation (01.11.1996-01.05.1997). The gas production of $3,000 \mathrm{Sm}^{3} /$ day was kept for two days (02.11.1996-03.11.1996) and increased up till 5,000 $\mathrm{Sm}^{3}$ on the $4^{\text {th }}$ day (04.11.1996) for Scenario 8. On the $5^{\text {th }}$ and $6^{\text {th }}$ day (05.11.1996-06.11.1996) of simulation, the gas injection was again decreased to 3,000 $\mathrm{Sm}^{3}$. Periods of 5,000 $\mathrm{Sm}^{3}$ and 3,000 $\mathrm{Sm}^{3}$ were continuously repeated.

In the case of Scenario 9, there was injection of 7,500 $\mathrm{Sm}^{3}$ of water every fourth day. The pattern for water injection went in the following order: 01.11.1996-7,500 $\mathrm{Sm}^{3}, 05.11 .1996-$ 7,500 $\mathrm{Sm}^{3}, 09.11 .1996-7,500 \mathrm{Sm}^{3}, 13.11 .1996-7,500 \mathrm{Sm}^{3}$, $\ldots$ end 01.05 .1997 .

The gas production was simulated in the following order; $1^{\text {st }}$ day $(02.11 .1996) 3,500 \mathrm{Sm}^{3}, 2^{\text {nd }}$ day $(03.11 .1996) 1,600$ $\mathrm{Sm}^{3}, 3^{\text {rd }}$ day (04.11.1996) $1,200 \mathrm{Sm}^{3}, 4^{\text {th }}$ day (05.11.1996) 500 $\mathrm{Sm}^{3}$. From the $5^{\text {th }}$ day the pattern was repeated over again. $5^{\text {th }}$ day $(06.11 .1996) 3,500 \mathrm{Sm}^{3}, 6^{\text {th }}$ day $(07.11 .1996) 1,600$ $\mathrm{Sm}^{3}, 7^{\text {th }}$ day $(08.11 .1996) 1,200 \mathrm{Sm}^{3}, 8^{\text {th }}$ day $(09.11 .1996), 9^{\text {th }}$ day (10.11.1996) $500 \mathrm{Sm}^{3}$. This pattern of four various gas productions was repeated till the end which was on 1.5.1997.

For Scenario 10, 6,000 $\mathrm{Sm}^{3} /$ day of water was injected for period of seven days (01.11.1996-07.11.1996). Corresponding days of water injection were followed by the gas production of 3,000 $\mathrm{Sm}^{3} /$ day (02.11.1996-08.11.1996).

Next week the water injection stopped and no gas was produced. A week of no water injection was from 07.11.1996 to 13.11.1996 and no gas production was from 08.11.1996 to 14.11.1996. Next, seven days of water injection were simulated between 14.11.1996-20.11.1996 and corresponding gas production between dates 15.11.1996-21.11.1996. Next week was without water injection and gas production. This pattern was repeated for the full period of the simulation.

\subsection{Simulation results}

The simulation of the daily oil production is shown in Fig. 4 for the evaluation of proposed MEOR application 
efficiencies. Scenario 1, where only water was injected, was denoted as a thick green curve. The oil production for the given well started in August 1996 and the maximum was reached after two months. From October 1996, the oil production had a declining tendency and it was decided to apply MEOR at this moment.

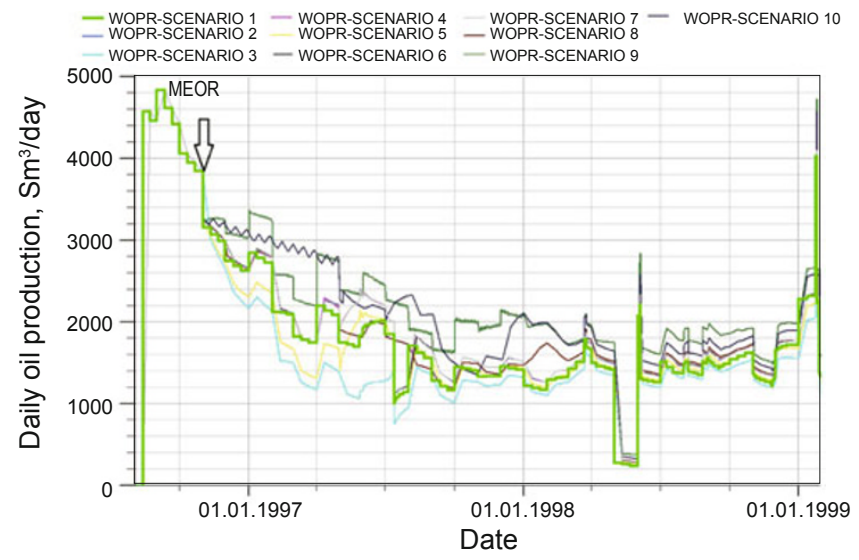

Fig. 4 Well oil production rate per day (WOPR) from ten different scenarios

Scenario 9 showed its highest oil production per day in the period after the $1^{\text {st }}$ of January 1997. On the contrary the scenarios 3 and 5 showed lower oil production than the base simulation in the whole period of the production and it led consequently to the conclusion that both options were not economically profitable. Scenario 4 had the same oil production as the base simulation. Scenario 8 had the same tendency as Scenario 4, but there was a slight increase in oil production after the $1^{\text {st }}$ of January 1998 and due to this reason it could be also considered for the field application.

The cumulative oil productions of all ten scenarios are shown in Fig. 5. It can be seen once again that scenarios 9 and 10 provided the highest production of oil, which mean that the lowest amount of water injected in the reservoir is producing the highest recovery. The maximum average incremental recoveries of $21 \%$ and $17.8 \%$ compared to blank Scenario 1 were calculated for Scenarios 9 and 10 respectively. Scenario 6 was identical to blank scenario 1 where only water was injected. The lowest production with scenarios 3 and 5 was probably due to water injection being too high.

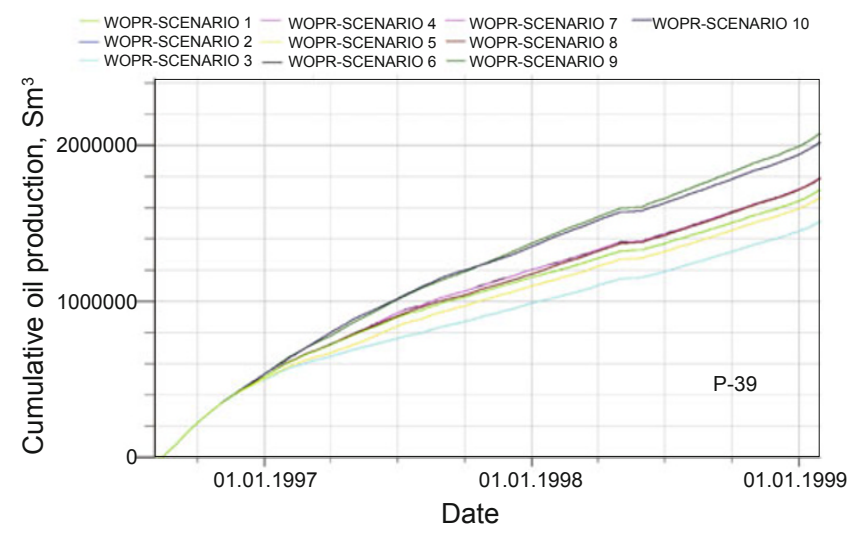

Fig. 5 Cumulative oil production (WOPT) for the 10 scenarios
Results of MEOR were compared with the FAWAG method performed the same pair of wells, where gas and surfactant solution were injected alternatively to increase oil recovery three years later in 1999 implying that the residual oil saturation was lower than in the period of assumed MEOR application. The average incremental recovery due to FAWAG was $9 \%$. Although the comparison can be made only for orientation, it shows that earlier application of EOR methods can be beneficial and that the simulation is a convenient tool to evaluate the potential of various methods.

The ratio of injection volumes of molasses to water was equal to $0.9 \%$ in each scenario, which means the average value of injected molasses for all scenarios is $2.4 \mathrm{Sm}^{3} /$ hour.

The lowest injections of molasses were calculated for scenarios 9 and 10. Injected molasses for scenario 9 was 0.7 $\mathrm{Sm}^{3} /$ hour and for scenario 10 was $1.3 \mathrm{Sm}^{3} /$ hour. The values of total injected molasses were 3,037.5 $\mathrm{Sm}^{3}$ (Scenario 9) and 5,553.9 $\mathrm{Sm}^{3}$ (Scenario 10). The estimation of price for the total injected molasses was from 394,875 USD to 722,007 USD based on the current price of $150 \mathrm{USD} / \mathrm{Sm}^{3}$ in 2013 .

For instance the price of injected surfactant Alpha olefin sulfonate (AOS) 16 for FAWAG project (1999-2000) was 1 Mil USD.

According to aforementioned calculations MEOR performance seems to be cheaper and more environmentally friendly.

Another assumption was made regarding the gas composition produced by bacteria. Injected hydrocarbon gas in Western and Central Fault Blocks of Snorre Field contained $70 \% \mathrm{CH}_{4}$ (Enick et al, 2012) and $30 \% \mathrm{CO}_{2} . \mathrm{H}_{2}$ and $\mathrm{N}_{2}$ are close to Ribe biogas with slightly lower content of $\mathrm{CH}_{4}$ and higher content of $\mathrm{CO}_{2}$. Due to that, the composition of gas in specification at the start of simulation was not changed. However, it is known that young cultures of anaerobic bacteria containing thousands of various strains produce $\mathrm{CO}_{2}$ at the beginning during quite a long period before $\mathrm{CH}_{4}$ production. Due to that, and probably due to use of molasses as a nutrient source, our preliminary laboratory investigations showed that the gas composition changed in the direction of significant $\mathrm{CO}_{2}$ increase and varied with salt concentration (unpublished data). The $\mathrm{CO}_{2}$ production can be a favorable factor because its presence decreases the demand for reaching minimum miscibility pressure (MMP) in the reservoir conditions. The MMP for $\mathrm{CO}_{2}$ is substantially lower than for dry hydrocarbon gas, flue gas, or nitrogen. Due to this reason MMP for $\mathrm{CO}_{2}$ projects can be achieved at attainable pressures in a broad spectrum of reservoirs (Stalkup, 1992) and it is generally said to be the major advantage of $\mathrm{CO}_{2}$ miscible processes. However, the changes of gas composition with time and salinity require further investigation.

\section{Conclusion}

The experimental work with anaerobic bacteria found that they can adapt successfully to a high temperature and high salinity and produce progressively gas in appropriate volumes. The highest gas volumes of above $300 \mathrm{~mL}$ were produced at 70 and $90 \mathrm{~g} / \mathrm{L}$ per $700 \mathrm{~mL}$ of microbial solution.

Since only biological substances are used for MEOR 
injection, this technique is also considered environmentally friendly and a reasonable candidate for sustainable future development in the energy sector.

The simulations show that the best scenarios for MEOR application are those where water is injected seldom, and molasses are not added in large quantities. Best scenarios revealed that the incremental oil recovery can reach about $20 \%$ if applied at the earlier stage of EOR methods implementation.

\section{Acknowledgements}

The authors would like to thank Statoil ASA for authorizing data published in this paper, Ribe Biogas Plant for the provided anaerobic bacteria, and Schlumberger Technology Center for ECLIPSE software.

\section{References}

Aarra M G, SkaugeA and Martinsen H A. FAWAG: a breakthrough for EOR in the North Sea. Paper SPE 77695 presented at SPE Annual Technical Conference and Exhibition, September 29-October 2, 2002, San Antonio, Texas

Brown L R. Microbial enhanced oil recovery (MEOR). Current Opinion in Microbiology. 2010. 13(3): 316-320

Donaldson E C, Chilingarian G V and Yen T F. Microbial Enhanced Oil Recovery. Vol. 22, Netherlands: Elsevier Science, 1989

Enick R, Olsen D, Ammer J and Schuller W. Mobility and conformance control for $\mathrm{CO}_{2}$ EOR via thickeners, foams, and gels: a literature review of 40 years of research and pilot tests. U.S. Department of Energy, 2012

Jimoh I A, Rudyk S N and Sogaard E G. Microbial fluid-rock interactions in chalk samples and salinity factor in divalent $\mathrm{Ca}^{2+}$ ions release for microbial enhanced oil recovery purposes. Chemical Engineering Transactions. 2011. 24: 889-894

Lazar I, Petrisor I G and Yen T F. Microbial enhanced oil recovery (MEOR). Petroleum Science and Technology. 2007. 25(11): 13531366

Sayyouh M H, Al-Blehed M S and Hemeida A M. Possible applications of MEOR to the Arab oil fields. Paper presented at the J. King Saud Univ, 1993, Saudi Arabia

Skauge A, Aarra M G, Surguchev L, et al. Foam-assisted WAG: experience from the Snorre Field. Paper SPE 75157 presented at SPE/DOE Improved Oil Recovery Symposium, April 13-17, 2002, Tulsa, Oklahoma

Sørensen B. Renewable Energy Conversion, Transmission, and Storage. Netherlands: Elsevier, 2007

Spirov P and Rudyk S. Testing of Snorre Field FAWAG in new foam screening model. Oil \& Gas Science and Technology-Revue d'IFP Energies nouvelles. 2013. DOI: $10.2516 /$ ogst/2013193

Spirov P, Rudyk S and Khan A. Foam assisted WAG, Snorre revisit with new foam screening model. Paper SPE 150829 presented at North Africa Technical Conference and Exhibition, February 20-22, 2012, Cairo, Egypt

Stalkup F I. Miscible Displacement. SPE Monograph Series. Vol. 8, Richardson, TX: Henry L. Doherty Memorial Fund of AIME, 1992

Wagner M. Microbial enhancement of oil recovery from carbonate reservoirs with complex formation characteristics. In: Microbial Enhancement of Oil Recovery-Recent Advances. Edited by Donaldson E C. Vol. 31, Netherlands: Elsevier Science, 1991

Weiss A, Jérôme V, Freitag R and Mayer H. Diversity of the resident microbiota in a thermophilic municipal biogas plant. Applied Microbiology and Biotechnology. 2008. 81(1): 163-73

Youssef N, Elshahed M S and McInerney M J. Microbial processes in oil fields: culprits, problems, and opportunities. Advances in Applied Microbiology. 2009. 66: 141-251

(Edited by Sun Yanhua) 